\title{
Public-Private Substitution in Higher Education Funding and Kondratiev Cycles: The Impacts on Home and International Students
}

Vincent Carpentier, Institute of Education, University of London, UK

\section{Introduction}

This chapter provides historical analysis of the position assigned to income from home and international students in the UK, France and the USA taking account of long economic cycles (Kondratiev cycles). The analysis uses historical datasets on the level and structure of the income of universities and the number and characteristics of students since the 1920s. These are interpreted using the theory of systemic regulation which examines the links between economic fluctuations, State action and social change (Fontvieille, 1976; Boccara, 2008). Such a framework offers a way to identify a succession of regimes of higher education which express the articulations (and tensions) between access and funding policies. Those impact on the rise or reduction of inequalities over time (Carpentier, 2006a). The presence of international students is an important, but generally overlooked, aspect of this.

Section 1 explores contemporary form of globalization with its stance on the control of public funding, the impact of economic cycles on the historical fluctuations of public resources devoted to higher education. It draws out the rise of private resources mobilized for higher education since the mid-1970s. Section 2 shows that the impact of these transformations on university resources is different according to whether the rise of private funding (observed in all countries) was used as a substitute for slower growth of public funding or as additional income for universities with rather different transformations of the public/private structure of universities' income in each country. The analysis focuses on fees, the main lever of private resources in universities, and looks at the impact on access and potential inequalities (Section 3) highlighting significance assigned to international students (Section 4). 


\section{Globalization, higher education and economic cycles: Approach and methodology}

The tensions between access to higher education and funding policies (Carpentier, 2006a) will be analysed through the lens of the theory of systemic regulation, which seeks to provide an explanation of the historical expansion of public expenditure on education in relation to long economic cycles (Carpentier, 2007). Cycles are not deterministic instruments but provide, using the lenses of historical political economy, ways of looking at changes and continuities (Hobsbawm, 1997; Goodson, 2006; Milonakis and Fine, 2009). A cyclical analysis of higher education funding will help to examine how the historical development of education 'reflects, and at times challenges the social, economic, political and intellectual context of its age' (Aldrich, 2002, p. 3). Through this, the dialogue between economic history and history of education (McCulloch, 1998; Sanderson, 2007) is extended to higher education (Silver, 2006; Lowe, 2008).

With regards to higher education, globalization is a multifaceted concept and a complex process (King, 2004; Marginson and van der Wende, 2007). While internationalization is generally used to define increasing links or exchanges between nations, globalization tends to refer to practices adopted across nation states (Held and McGrew, 2002). These global practices have impacted on higher education as 'the economics of globalisation is an increasingly important point of reference in national educational policy making' (Ball, 2008, p. 39). The 'repositioning of higher education as a global commodity' (Naidoo, 2003, p. 254) impacts on universities' engagement with internationalization (Byram and Dervin, 2008, p. 2). Both need to be placed in historical perspective.

Castells (2000) distinguishes a world economy from a global economy and links the latter with ICT and policies of deregulation. Such policies are associated with the contemporary neoliberal form of economic globalization. Wallerstein (2003) suggests that globalization is not new and that the post 1990s period is a moment of crisis and transformation of the world system which long predates it (2003). The major economic turbulences of 2008-2009 seem to confirm that we are at a turning point with regard to the forms of globalization and deregulation. Long economic cycles offer a perspective on 
contemporary globalization by locating its specific discourses and practices as a particular form of a movement of internationalization. Two dimensions of the contemporary form of globalization strongly impact on higher education: firstly a constant reference to the knowledge economy - that is the idea of competition increasingly based on knowledge in an open world economy which has been a powerful driver of educational policies, often to the detriment of other rationales (Wolf, 2002). Second, globalization has been associated with a low tax economy and control of public funding endorsed by the 1980s Washington Consensus with its neoliberal emphasize on individualism and market (Serra and Stiglitz, 2008). Tensions between these two agendas are evident within higher education: the expansion of enrolment is seen as a priority for the globalized knowledge economy, but this sits uneasily with pressure for a limitation of state funding despite the fact that historically higher education has expanded through state investment. Tensions are played out in ongoing debates on underfunding. These result from a combination of expanding numbers with inadequate resources which put increasing pressure on universities, staff and students (Olssen and Peters, 2005).

This chapter explores the consequence of these tensions in relation to inequalities as they relate to domestic and overseas students. It will examine how a traditional form of internationalization of higher education (the enrolment of overseas students) interacts or clashes with an emerging form of neoliberal globalization, that is the transformation of university income structure and a search for global private resources. Inequalities emerge out of the dynamic of concern with funding and access. Although this excludes issues of identities and inequalities, 'the importance of recognising how multiple identities and inequalities of 'race', ethnicity, social class and gender (amongst others) affect the way in which people construct, experience and negotiate different educational opportunities and routes' (Archer and Leathwood, 2003, p. 175) is acknowledged. Persistent inequalities within higher education, while related to financial capital, are also articulated to cultural capital and social capital (Bourdieu and Passeron, 1964; Apple, 1982; Reay et al., 2005). Much of the inequality of access to higher education is due to inequality at the compulsory school level (Galindo-Rueda et al., 2004). While this is not explored in depth 
here, it is argued that in these challenging times funding issues and fees are important aspects of inequalities.

Quantitative analysis in relation to economic cycles is used to illustrate transformations of university funding and access of home and overseas students. However, it is important to stress that numbers offer promises to enhance interpretation but also have important limitations. Quantitative methods are thus used to identify trends and patterns and facilitate contextualization (Carpentier, 2008). Historical data on funding and enrolment at universities in France, the UK and the US since the 1920s (Carpentier, 2004, 2006a, 2006b) are analysed using the method of quantitative history. This method follows principles of national accounting, which provide a stable frame to integrate financial and other relevant data, and allow comparison across time and space (Marczewski, 1961). Funding indicators include the income of universities and its structure (public grants, fees, donations). Non-financial data include the number of home and overseas students. The data on domestic students have been extracted from previous work. In addition, new data on international students have been compiled from statistical reports from the Higher Education Funding Council and its predecessors. ${ }^{1}$ For the UK, data are supplied only for universities until 1994. Afterwards, data relating to advanced courses in polytechnics and advanced further education (which became universities after the 1992 Higher Education Act) are included. French and US Data relate to all higher education institutions (public and private).

\footnotetext{
1 University Grants Committee (1966-1979) Statistics of Education, Vol. 6, University statistics, Universities' Statistical Records, Vol. 3, London; University Grants Committee (1980-1988) University statistics, Vol. 1, Students and Staff, Universities' Statistical Records, London; University Funding Council (1980-1988) University statistics, Vol. 3, Finance, Universities' Statistical Records, London; University Funding Council (1989-1994) University statistics, Vol. 1, Students and Staff, Universities' Statistical Records, London.; University Funding Council (1989-1994) University statistics, Vol. 3, Finance, Universities' Statistical Records, London.; Higher Education Statistics Agency (1995-current) Resources for Higher Education Institutions, Higher Education Statistics Agency Limited, Cheltenham.; Higher Education Statistics Agency (1995-current) Students in Higher Education Institutions, Higher Education Statistics Agency Limited, Cheltenham.
} 


\section{Public funding of universities and Kondratiev cycles}

Figure 1 shows there has been from 1920 to 2006 an increase in the expenditure per student in all three countries.

Figure 1 University expenditure per student (1990 Geary-Khamis \$) 1921-2006 ${ }^{2}$

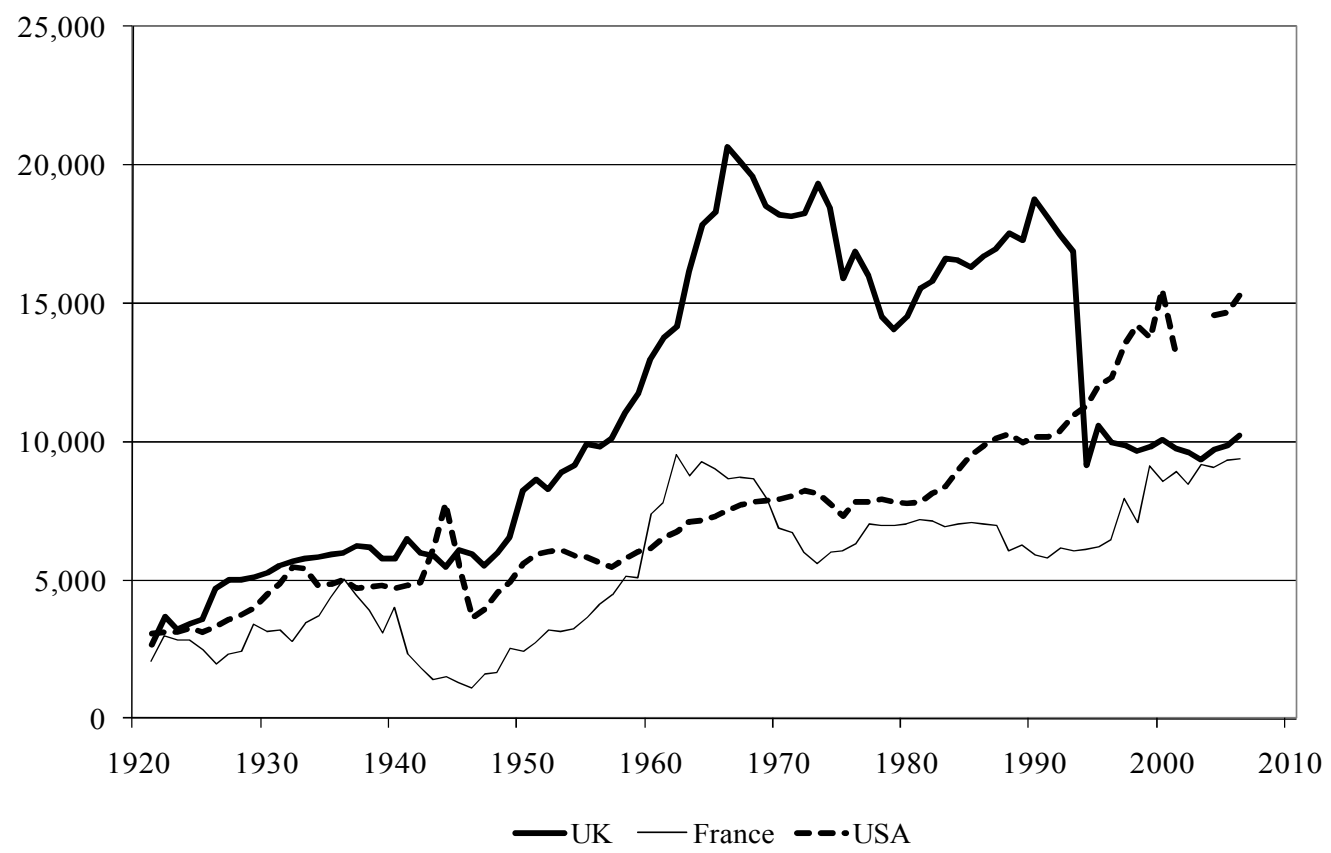

There is a higher level of funding per student in the US than in France and the UK. Trends in funding per student have been fairly regular in the US, less regular in France and chaotic in the UK. However, it should be noted that the fast decline of the funding per student in the UK in 1993 was due to the integration of post 1992 institutions (whose funding per student is lower than pre 1992 universities). Nevertheless, it is apparent that

\footnotetext{
${ }^{2}$ Financial series are expressed in purchasing power parity in 1990 Geary-Khamis US \$ (PPP). PPP can be defined as a conversion rate that quantifies the amount of a country's currency necessary to buy in the market of that country the same quantity of goods and services as a dollar in the US. Such a tool is necessary in order to give a comparative estimate of the value of educational expenditure eliminating differences in price level between countries. The PPP indices series are derived from Maddison's calculation of GDP at PPP US \$ (Maddison, 1995; 2000) and updated (http://www.ggdc.net/maddison). The GDP at PPP US $\$$ was then divided by the GDP expressed in current $\$$ to obtain the PPP index and applied to the expenditure series.
} 
such decline was already on its way in the late 1980s when the tensions between access and funding policies started becoming visible.

These historical patterns are at the core of contemporary debates on underfunding in France and the UK. In a context of continuous expansion of enrolment, the controversies can be further understood by an examination of the fluctuations in public funding available to universities. Figure 2 indicates a strong correspondence between public spending on higher education and long economic cycles (Kondratiev cycles or Long waves) in France, the UK and the USA (Carpentier, 2001, 2006b).

Figure 2 Fluctuation of public expenditure on higher education (1990 Geary-Khamis $\$$ ) (second order deviation from the regression curve) 1921-2003 ${ }^{3}$

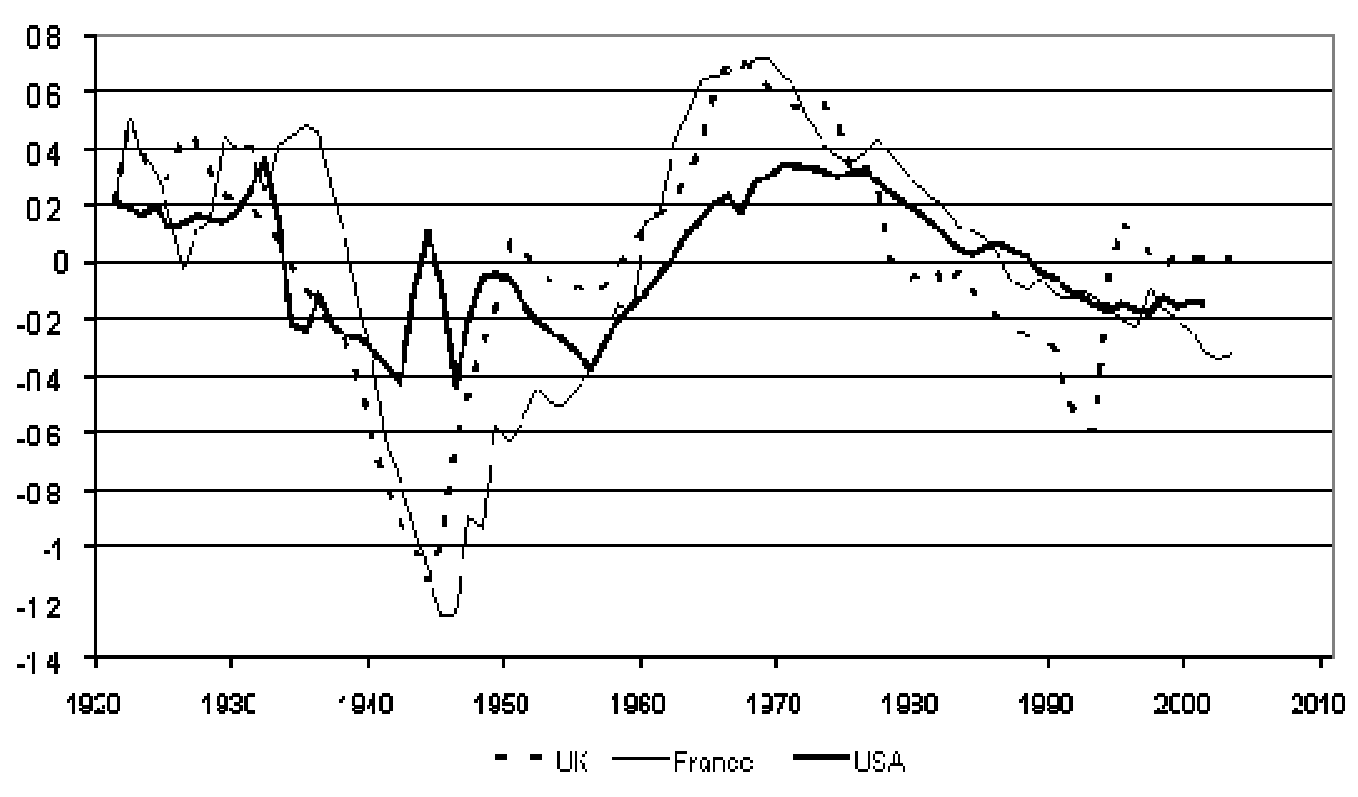

\footnotetext{
${ }^{3}$ A regression curve is the best-fitting curve drawn through a scatter-plot of two variables. It is chosen to come as close to the points as possible. A regression curve represents then the shape of the relationship between the variables (here the expenditure and the time) and the long-term trend if the series were regularly distributed. The deviations from the regression curve represent the cyclical fluctuations around the trend. Nine-year moving averages are sliding averages that smooth the data in order to ease the examination of the trend and changes.
} 
Named after the Russian Economist, Nikolai Kondratiev (1892-1938), four Kondratiev cycles of approximately 50 years have been identified, each showing expansion and depression phases (1790-1820/1820-1848, 1848-1870/1870-1897, 1897-1913/19131945, 1945-1973/1973-?) (Loucã and Reijnders, 1999). The graph shows a remarkable correlation: in all the three countries, the growth of public educational resources accelerated during the period of post-war prosperity, only to go into relative decline following the early 1970s economic downturn precipitated by the oil crisis of 1973 . The 2008-2009 crisis may suggest that this downward phase is still going on (Carpentier, 2009). The revival in public expenditure in the early 1990s in the UK is due to the sudden integration of colleges and polytechnics within the university system, but the effect is temporary, as the downward trend continues after this.

While it is difficult to conclude about a clear causal relation, these cyclical fluctuations in public funding of higher education may be connected to development of and crisis in the welfare state. Change in higher education can be understood as part of a wider trend which links the State and the transformation of the socio-economic system. Regulation theories have mapped this (Boyer and Saillard, 2002). The theory of systemic regulation interprets the Kondratiev cycle as an expression of recurrent structural transformations of the capitalist system (Marx, 1894; Fontvieille, 1976; Boccara, 2008). Amongst these transformations, the theory identifies a reversal of the historical relationship between economic cycles and human development around the Second World War. This reversal was revealed by the observation of a transition from a countercyclical to a procyclical growth of public spending (Michel and Vallade, 2007). Before 1945, increased levels of public investment in human development took place during long economic downturns (1830s-1850s/1870s-1890s and 1920s-1940s). Such investments (which were seen as unnecessary during the economic upturns) offered opportunities to use an overaccumulated capital to revive productivity levels and provided an escape route out of socio-economic crises. After 1945, a shift occurred as public funding of social development became not only a way out of the crisis but a driver of economic growth. The post-war economic upturn 1945-1973 was driven by the implementation of Keynesian redistributive policies as well as an acceleration of social spendings which 
contributed to human development necessary to drive productivity levels. This regime hit a crisis in the mid-1970s when stagflation was countered with the adoption of Neoliberalism. Wage austerity as well as the retreat of State funding since the 1970s is a global phenomenon which has affected nearly all social activities. Jessop has interpreted this as a gradual transition from the Keynesian welfare State to a Schumpeterian competition State focusing on innovation and subordinating the social sphere to economic policy (2002).

In the economic crisis of the mid-1970s for the first time a long economic downturn was accompanied by a slowdown in the growth of public funding for the social sphere. During previous crises (1830s, 1870s, 1930s), the dynamic of the economy was revived by the development of a social infrastructure whose logic was not driven by profit. In the 1970s, there were tensions between these two forms of regulation. The neoliberal agenda may be understood as a way to switch back the social infrastructure of human development to a form of capitalist regulation. Neoliberalism may thus be interpreted as interrupting social transformations. But the economy has not really recovered from the downturn of the early 1970s. Instead the overaccumulation of capital was directed towards the financial sphere with catastrophic results, for example the implosion of the financial system in 2008. The 2008-2009 crisis may therefore be seen as the continuation of a long Kondratiev downswing and an opportunity to develop social and ecological innovations towards a more inclusive growth (Carpentier, 2009). Indeed, this framework suggests that the relationship between the social sphere and the economy is historically contingent. It has changed in the past and may be different in the future. The scale of the current economic crisis challenges the post 1970s discourse of irreversibility of change and may open up an alternative view on the contemporary orthodoxy of limited taxation restricting social progress.

A research programme confirmed such a link between education and Kondratiev cycles, showing that the development of educational systems during downward economic phases like the $1840 \mathrm{~s}, 1870 \mathrm{~s}$ and the $1930 \mathrm{~s}$ may have contributed to revive productivity (Fontvieille, 1990; Carry, 1999; Michel, 1999; Diebolt and Fontvieille, 2001; Carpentier, 
2003, 2006b). The research also confirmed the Second World War as a period of reversal revealing that funding of public education systems benefited from and indeed contributed to the post 1945 economic upturn before being particularly hurt by constraints on public finances in the 1970s downturn. This research focused on industrialized countries (France, Germany, the UK and the USA). As such, the comparison does not explain the process in all countries. One should expect a more mixed picture in Africa or Asia. However, other works in Algeria and Senegal have shown that many developing countries experienced similar patterns with increases in public funding from the 1960s followed by drastic public sector reform with the structural adjustment policies of the 1980s (Bouslimani, 2002; Diouf and Fontvielle, 2002). In India, tensions between the demands of the knowledge economy and public funding have emerged (Chattopadhyay, 2007).

Figure 2 confirms such a correlation between public funding in higher education and Kondratiev cycles. The sector benefited from the post-war upturn and was particularly exposed to cuts in public funding in the 1970s leading to substantial changes in its income structure as it will be shown below (Carpentier, 2006a). How has the public/private distribution of funding changed and how has it impacted on inequalities?

\section{Changes in the universities' income structure: Are fees drivers of public-private substitution or additional resources?}

Cyclical fluctuations in public resources have impacted on university income differently in France, the UK and the USA and with different consequences for access. The extent to which increased private resources have acted as a substitute for slower growth of public funding or additional income for higher education raises questions about the role fees from home and overseas students play.

Figure 3 shows substantial changes in the balance between private and public income for universities since the 1920s. 
Figure 3 Fees and public funding as a share of universities' income: 1921-2006

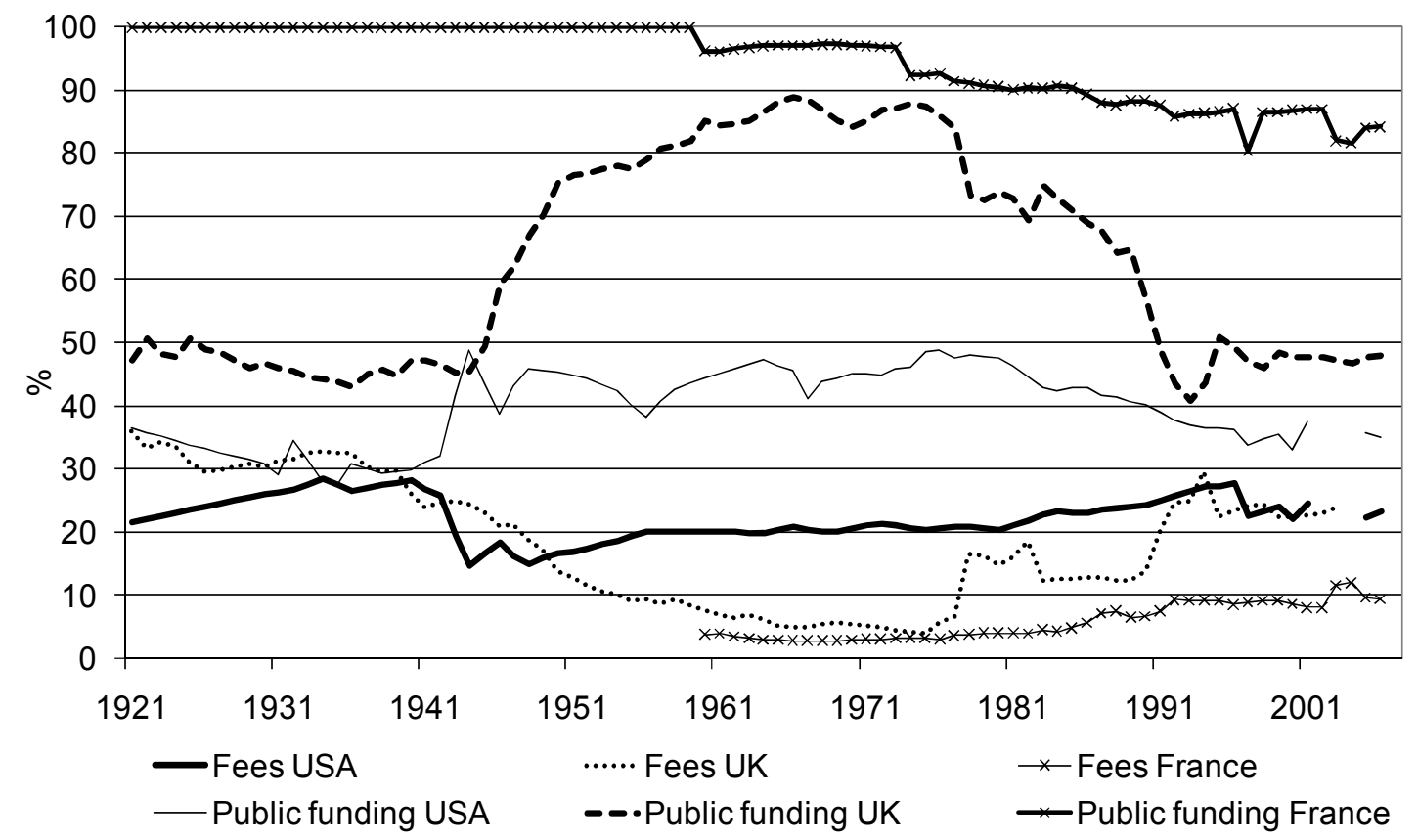

In the UK, the share of income from public sources grew from 50 per cent to nearly 90 per cent from 1945 to 1973, but contracting to around 50 per cent in the late 1990s (the accounting category 'other income' which does not separate public from private funding has grown substantially - therefore, a more accurate estimation of the share of public income may be closer to 55 per cent). In the USA, much less radical changes occurred with a growth from 38 per cent to 50 per cent between 1945 and 1973 and a post 1970s decline back to 38 per cent. In France, the transformation is much smaller as public funding supplied 96 per cent of university resources in 1960 against 84 per cent at the turn of the century.

Table 1 shows the post 1970s slowing down of growth of public funding (linked to Kondratiev cycles) was more extensive than the subsequent rise of private resources. 
Table 1 Multipliers of public, private and total income of universities (1990 GearyKhamis \$) 1921-2006

\begin{tabular}{|l|l|l|l|l|l|l|l|l|l|}
\cline { 2 - 10 } \multicolumn{1}{c|}{} & \multicolumn{3}{c|}{ US } & \multicolumn{3}{c|}{ UK } & \multicolumn{3}{c|}{ France } \\
\cline { 2 - 11 } \multicolumn{1}{c|}{} & Public & Private & Total & Public & Private & Total & Public & Private & Total \\
\hline $\begin{array}{l}1921- \\
1945\end{array}$ & 5.51 & 4.13 & 4.63 & 2.35 & 2.15 & 2.25 & 1.22 & - & 1.22 \\
\hline $\begin{array}{l}1945- \\
1973\end{array}$ & 9.10 & 8.33 & 8.66 & 30.30 & 4.40 & 17.19 & 37.02 & 2.75 & 38.26 \\
\hline $\begin{array}{l}1973- \\
2006\end{array}$ & 2.67 & 4.15 & 3.47 & 2.48 & 18.71 & 4.58 & 3.54 & 31.55 & 4.44 \\
\hline
\end{tabular}

The transformation of the structure of university income that followed meant that although there was some growth in the total available, it was not equivalent to the income that would have been available if the dynamic of public funding had continued (Carpentier, 2006a).

In France, and especially in the UK, private funding (including fees) increased in order to substitute for slower growth of public funding, rather than taking the form of additional resources. The substitution was less important in the USA where total income relied on a greater balance between public and private resources (including drivers like military expenditures and high levels of student debt). This explains the higher spending per student seen in Figure 1. One interpretation of persistent underfunding in higher education is that private funding should have been increased further. However, alongside the obvious objection in relation to the commodification of higher education, this raises issues regarding the socially acceptable levels of fees and the volatility of private resources. This is especially pertinent in the current crisis. Another interpretation points at insufficient levels of public funding since the 1970s' crisis (in contrast with previous economic downturns). The main lesson from this is that extra private resources do not necessarily lead to a substantial overall rise in the income of universities. Public-private substitution of resources rather than a substantial increase of funding might be a 
paradoxical outcome of reforms which seek to introduce private funding (and especially fees) in France and the UK (Belloc, 2003; DfES, 2003).

Various types of private resources are available to universities such as endowments, donations, research contracts and commercial services, but fees remain the main resource with the biggest impact on access. Fees have been at the forefront of a worldwide 'cost sharing' strategy which intends to bring about a 'shift of some of the higher educational per students costs from government and taxpayers to parents and students' (Teixeira et al., 2006). Figure 3 shows that the share of fees is traditionally high in the US and low (but increasing) in France. In the UK, from 1962, fees were covered by mandatory grants from Local Education Authorities. Following debates about underfunding in the 1990s, the Dearing Report recommended the introduction of fees with means-tested grants (1997). The 1998 Higher Education Act only partially followed Dearing's recommendation (Watson and Bowden 2007). It introduced upfront fees (£1000) but replaced grants by loans at preferential rates. More recently, the publication of the 2003 White Paper on the Future of Higher Education generated heated debates about the alternative ways in which funding, quality and the widening participation agenda could be connected. Debates focused on the potential impact on access and participation of the proposed top-up fees for home students. The disputed vote on the 2004 Higher Education Act led to the replacement of the $£ 1000$ upfront fees by deferred variable fees of up to $£ 3000$ (only payable when a graduate earns more than $£ 15,000$ ). A grant of up to $£ 2700$ for a family earning up to $£ 20,000$ a year was reintroduced. Supporters of the reform invoked the equity issue arguing a predominantly middle-class student body was getting private financial and cultural benefits by working-class taxpayers. They argued that deferred fees and the reintroduction of a grant will allow a continuing expansion of enrolment while resolving the underfunding issue (Barr, 2003). Counterarguments stressed the impact of higher fees on the actual and perceived level of debt on workingclass students (Callender and Jackson, 2005). Variable fees are thought to be a potential source of inequalities between institutions (Brown, 2004). 
The first years of implementation of the Higher Education Act of 2004 seem not to have impacted on access but there are still uncertainties. There have been mixed signals. On the one hand, the Brown government in 2008 increased the income threshold for being eligible for a grant from $£ 25,000$ to $£ 60,000$ : this suggests some concerns in terms of access (the maximum threshold has since been reduced to £50,000). On the other hand, there are pressures for lifting the cap on fees. This proposal was made in a rosier economic context with high level of employment and one should note that the impact of the 2008 economic crisis on unemployment, levels of private debt (and increased public debt due to banks bailout) and difficulty in getting loans from banks may change the terms of the debate about fees. At the time of the writing, funding and access policies are clashing more than ever with talks about higher fees, uncertainties about grants, caps on number of students and fewer mentions from politicians of the 50 per cent participation target. A Review of Higher Education Funding and Student Finance is under way. These debates will determine whether extra private funding will act as additional or substitute resources and the extent to which they will impact on access. The history of publicprivate substitution of funding suggests that an increase in fees, not supported by a rise of public funding, may not change the situation in terms of resources available and could produce more inequalities (Carpentier, 2006a). In the USA, expansion has been sustained because of a greater tradition of offering scholarships than in the UK and an acceptance of far higher levels of student debt (again this may change in the new economic context). In the UK and France, an increase of fees without additional public funding towards student financial support and pedagogy may have a negative impact on access, retention and achievements and severely hit the widening participation agenda.

An exacerbated public/private substitution would bring a situation where the agenda of austerity associated with the neoliberal form of globalization would play against the other agenda of the knowledge economy. However, this does not necessarily have to be the case. The levels of public debt brought about by the bailout of the financial sector in the current crisis could make a case for more money to be spent on productive social activities like higher education. This would mark a return to countercyclical spending as happened during the crises of the 1840s, 1870s and 1930s. However, a rationale for more 
cuts in higher education as a continuation of the neoliberal austerity of the 1970s could also develop.

Public-private substitution also raises questions about global higher education. Are strategies of internationalization generating additional or substitutive resources? And what are their effects on equity and access?

\section{International students and public-private substitution}

Increasing tensions between global agendas related to the knowledge economy and neoliberal austerity have not only impacted on higher education funding and equity within particular countries but have also changed the way universities engage with the process of internationalization. The concern with low taxation explains an increasingly economically driven rationale for the internationalization of higher education based on a search for private resources. This sits alongside more traditional, political and cultural arguments for internationalization. A concept like Borderless Higher Education encompasses diverse manifestations (Bjarnason, 2004) but summarizes well how new and old forms of internationalization are used as forms of income generation for exporting countries and capacity building for importing countries within an expanding global higher education market (Gürüz, 2008). Thus, high income countries create off shore campuses, export degrees physically or by distance learning or welcome international students as ways to generate extra revenue. On the other hand, governments of countries with limited amount of money to invest in public universities import programmes or institutions and send students abroad in order to develop their capacity. Initially, high income countries are the main providers of internationalization and they remain so, but it should be noted that more and more exchanges are taking place between developing countries. In comparing and contrasting international students and domestic students a complex inequality emerges. Williams remarked in the 1980s that 'the overseas student question has given rise to thoughts and speculations which may cause the landscape of British higher education to change out of all recognition by the end of the century' (1984, p. 277). UK overseas students were charged fees a number of decades 
before this was re-introduced for home students. Thus in 1967, the introduction of differential fees for overseas students paved the way for successive increases and culminated in the decision to introduce full cost fees for non EU overseas students in 1980 (and home rates for EU students). The 2004 Higher Education Act only levied variable fees on home students 40 years later. However, despite the introduction of fees, the number of overseas students grew fourfold from 1981. The steep growth in 1993 is partly due to the integration of new universities.

Figure 4 Overseas students in UK universities full time and part time 1981-2007

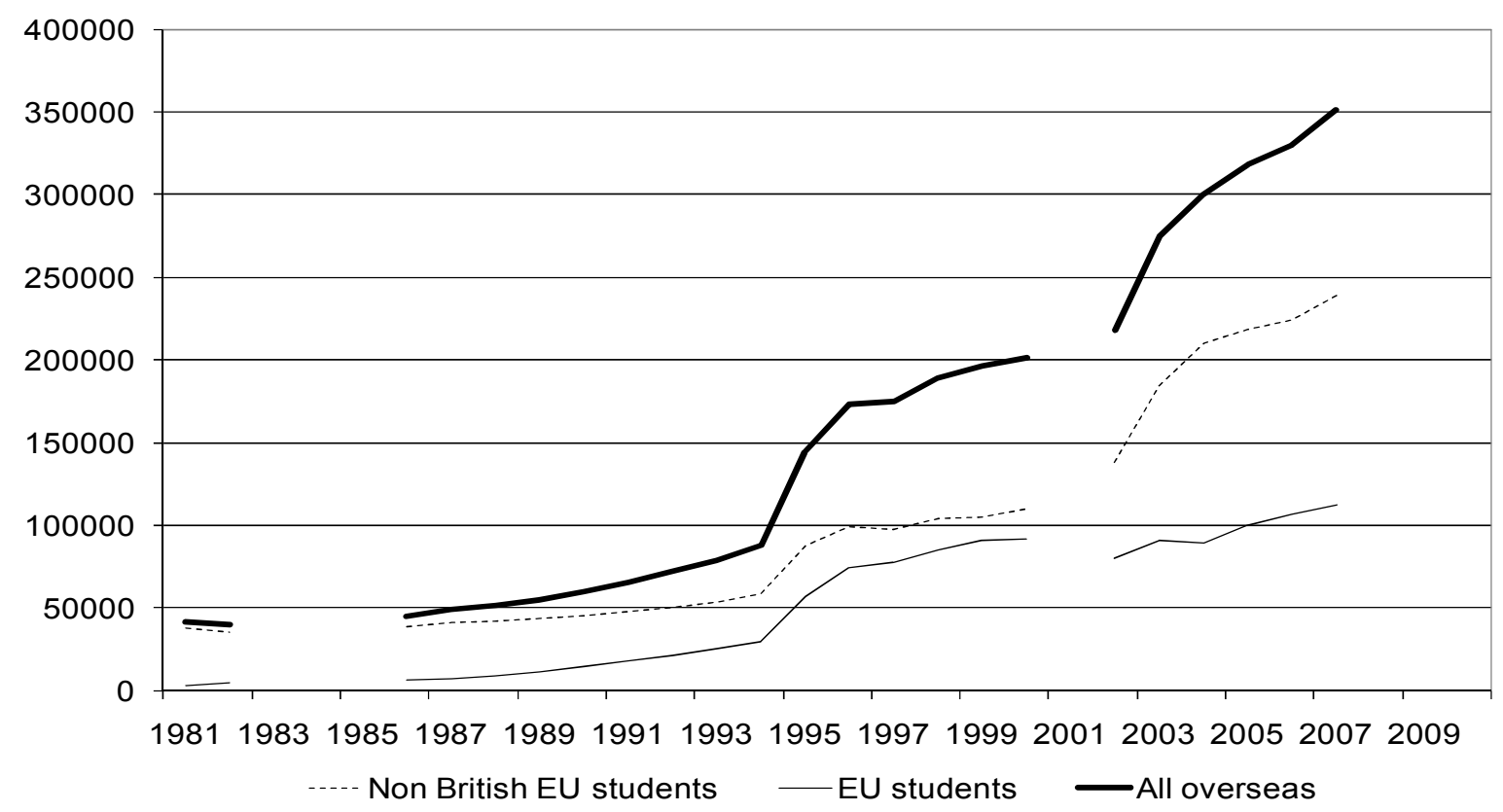

Figure 4 indicates that the dynamic of growth is due to growing enrolment of EU students in the mid-1980s who benefited from the 1980 agreement to charge them the same fees as domestic students. But there has been a sharp acceleration in the number of non EU students since the late 1990s.

Overseas students represented 15 per cent of total enrolment in UK universities in 2007 (17 per cent of full time and 9 per cent part-time students). Forty-seven per cent of overseas students are female. Thirty-two per cent came from the EU, 41 per cent from Asia (including 25 per cent from China) and 9 per cent from Africa (HEFCE, 2007). 
Seventy-five per cent undertook full-time study and 50 per cent study at undergraduate level.

The historical picture shows that the presence of international students in UK universities was not new (the proportion of overseas students was already 12 per cent in 1981). It was accelerated, rather than initiated, by the globalization process of the 1990s.

Figure 5 International students as a share of all full-time students, UK, 1920-2006

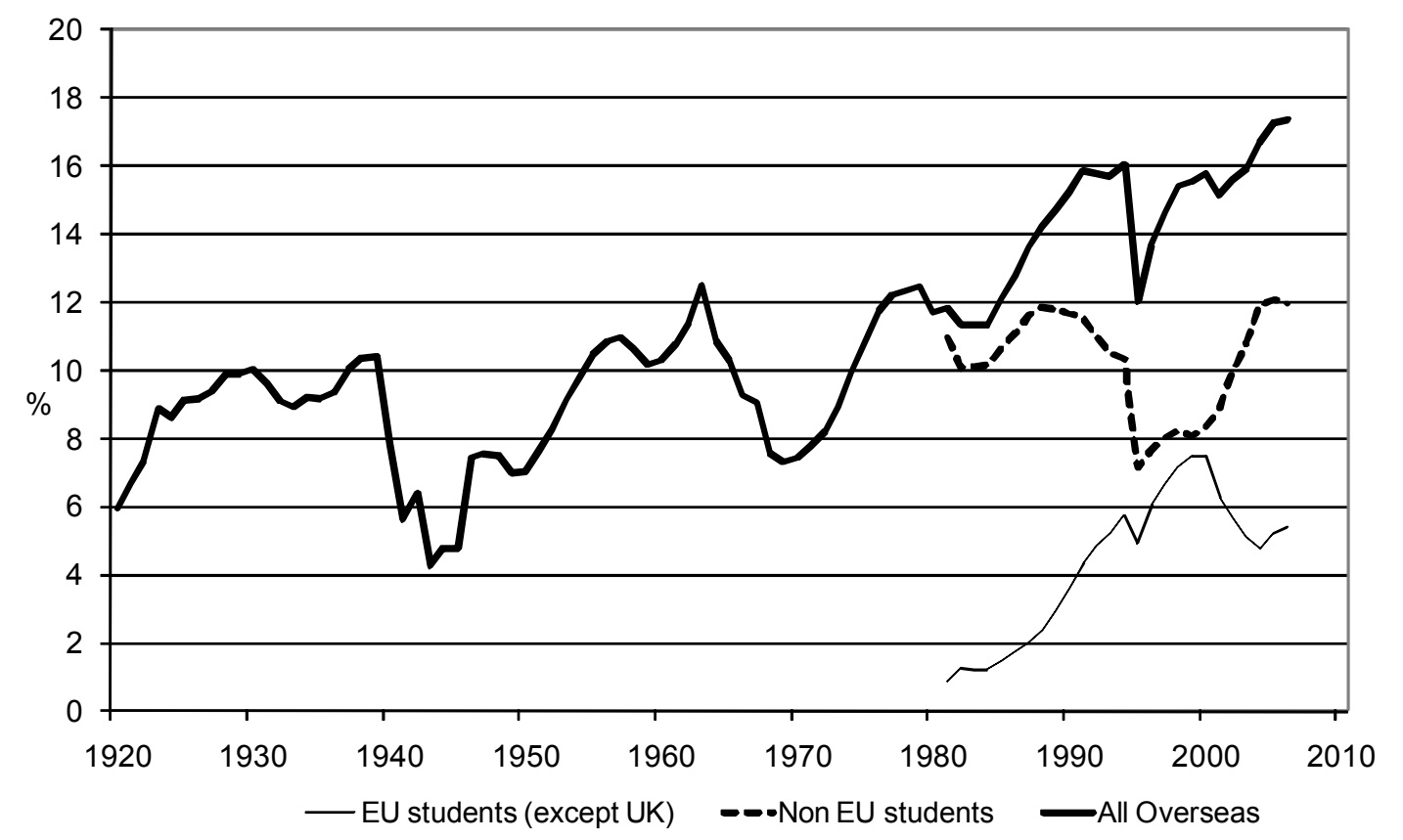

Figure 5 reveals important fluctuations but signals that the number of overseas students as a share of all full-time students has increased substantially since the 1970s. The graph confirms the EU students' enrolment has risen sharply since the mid-1980s. However, there has been a dramatic increase of the share of non EU overseas students since the 2000s.

Variations depend on a combination of deliberate or constrained choices and strategies from government. Changing cultural, political, social and economic factors have affected institutions and students across time and space. There are too many interrelationships at work here to be able to theorize the full complexity. However, it may be possible to 
unpack changing patterns of the place of international students since the early $1970 \mathrm{~s}$ within the higher education system by looking at private/public substitution.

Figure 6 Fees from overseas students as a share of universities' income: UK 19682006

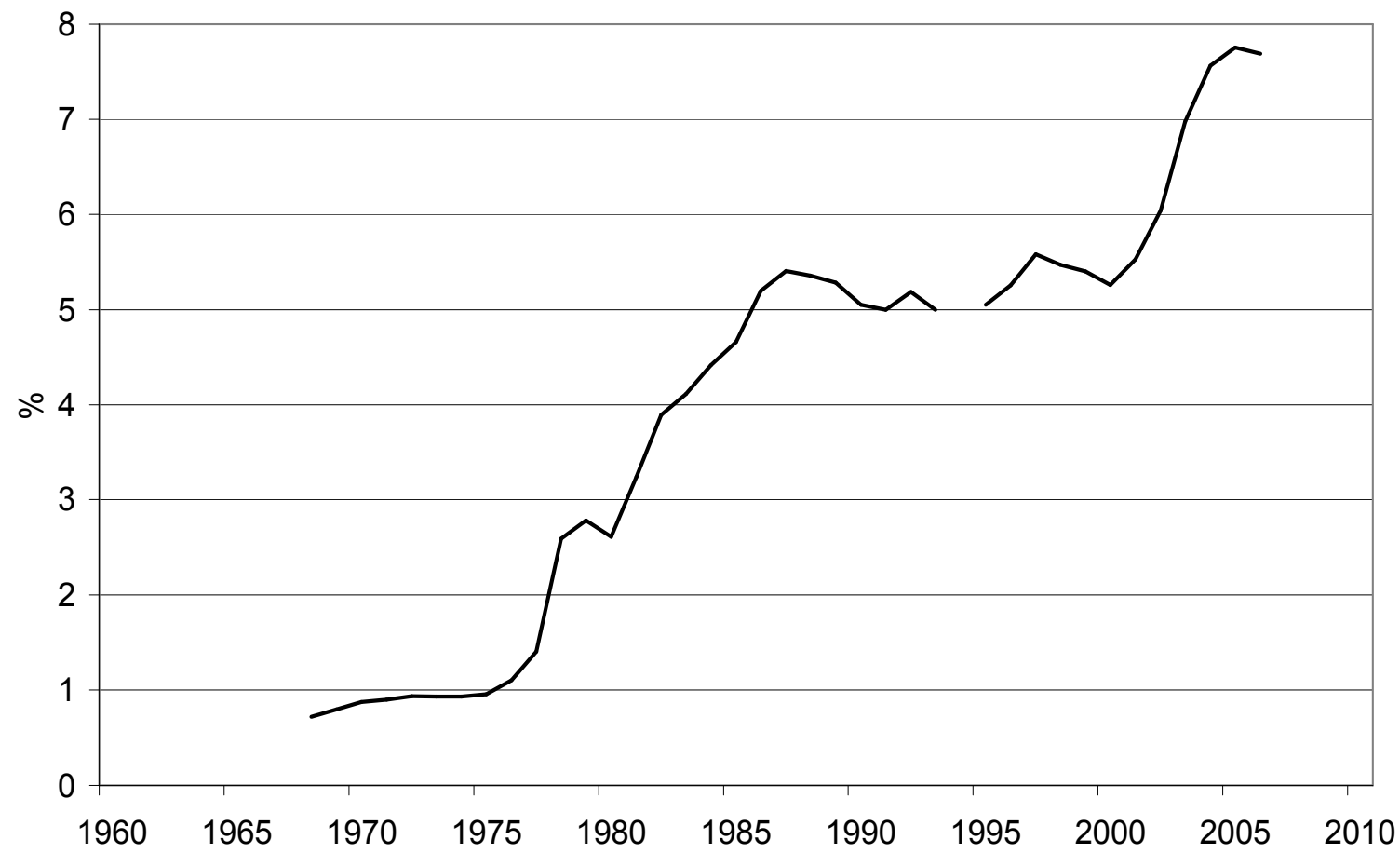

Figure 6 shows dramatic changes in universities' income from fees from overseas students. These are only partially mirrored by increases in enrolment. The share of enrolment by overseas students doubled in this period while their contribution to income grew eightfold.

Such patterns are consistent with the impact of the Kondratiev cycle on the retreat of public funding and pressure to rely on private funding. The graph suggests that in the context of a slowing down of state funding following the crisis of the early 1970s, overseas fees have been used as an instrument to generate extra funding and contribute to the trend for public-private substitution. There are, of course, other factors that could explain such a trend but it is difficult to ignore the fact that only 1 per cent of 
universities' income was generated by international students' fees in the early 1970s against 8 per cent today. The increase of overseas fees in the 1980s was clearly linked to the context of stagnating public funding (Williams, 1984; Sizer, 1987). The debate at the time revolved around the fact that overseas students were offered a subsidized education by the British State. For some this was problematic, for others an important investment in international relations for the future and a contribution to global justice (Enslin and Hedge, 2008). Since the 1980s, the situation has been reversed and 'institutions are using income from fee-paying students to upgrade resources and accommodation and to create additional student places' (Baker, 1993, p. 98). Thus subsidization is going from international to home students.

The fees charged to international students in UK universities were a forerunner of the public/private substitution of income. This happened at least a decade before the full impact of globalization policies and discussion of the importance of home student's contributions to the cost of their studies. Indeed, Harris, interestingly, argues that full cost overseas fees 'presaged over more radical shifts in university politics in the 1980s' (1997, p. 34). Since the crisis of the mid-1970s, changes in funding policies have had a strong impact on students. In some cases reforms led overseas and domestic students to share a common experience of high costs and in others they led to divergent paths. The publicprivate interface with regard to overseas students highlights a number of themes concerning the rationale for changed policy, stability, dependence, pedagogy and social justice.

The rationale for the particular political economy concerning the playing out of the balance between home and international students is in a way quite similar for both sets of students with regard to balance between fees, financial support and access. The cost/benefit analysis has been a strong determinant of policy decisions. This has tended to favour public/private substitution. Such an approach fails to integrate the whole picture. It tends only to acknowledge factors that can be measured. The argument for higher fees for overseas students rests on a denunciation of the cost of subsidizing overseas students who get substantial private benefits without offering social benefits to the country in which 
they receive their education, especially if they return to their home country. A counter argument is made which highlights economic benefits associated to overseas students. Fees are gained as well as the spending of overseas students and indirect resources (fiscal revenue and an increase of GDP if qualified students stay in the UK) (Vickers and Bekhradnia, 2007). It is clear that this debate is not facilitated by the fact that public and private costs (taxes and fees) as well as private benefits (wages) are far easier to evaluate than social economic benefits (GDP). Moreover, such calculations tend to put aside cultural and political benefits which are difficult to measure but indirectly contribute to society and the economy (not to mention learning for its own sake). Such asymmetry can explain why policies tend to view overseas students' recruitment in monetary terms as part of the public/private substitution strategy rather than incorporating important dimensions like social capital and cultural exchange (the same argument applies for domestic students' fees).

Fees policy is constantly moving and, by shifting priorities of funding strategies at the institutional level, can produce imbalances within the system. Scott states that there could be conflict between strategies and policies towards international and home students (Scott, 1998, p. 109). For example, Bolsman and Miller remarked that as a result of the increase of fees for home students in 2006, 'the differences between home and international student revenue is less marked at the undergraduate level and that the new market for overseas students has shifted to the postgraduate level' (2008, p. 4). This signals different positions and interests from institutions and government in relation to the public/private substitution framework: recurrent changes in fee arrangements (depending on whether money come either from government subsidy or home and overseas fees) affect an institution's approach of the recruitment of full cost overseas students and home students, not necessarily in line with government's intended goal. This illustrates the risk that different and sometimes contradictory political and economic rationales in order to increase or limit the numbers of home and international students could produce instability in the development of the whole higher education system. Ensuring stability would require a holistic approach on the conceptualization of fee 
policies driven by concerted efforts to align institutions, government and students' perspectives to guarantee a well-funded equitable HE system.

Public-private substitution increases the risk for universities' income to be exposed to a decrease of international students. Watson notes that 'the exposure of UK higher education to its international business is considerable' (2007, p. 30). The crisis in Asia in the late 1990s is a good example of the vulnerability to exchange rate that would lead to students' incapacity to pay for fees. Another example is the development of international competitors for overseas students. This is a pertinent issue in the UK where the average proportion of foreign students to all students is far higher (15 per cent) than in France (8 per cent) or the USA ( 4 per cent). The long-term slowing down of public funding provoked by public/private income substitution cannot be easily reversed to compensate for potential shorter shocks like the withdrawal of students' fees. The point here is not to limit overseas students' number but to sustain public funding in order to prevent universities' overreliance on overseas students' fees. This point can be generalized to other private sources of funding (domestic fees, donations, private funding of research) and is particularly relevant in the context of the current economic crisis which may affect student mobility.

Increased overseas fees as a substitute for slower public funding rather than an additional resource raise questions about whether sufficient investment is directed towards the adaptation of the pedagogic environment to diversity (this concern also applies to domestic students). According to Williams, 'in the 1960s and 1970s the anxiety was almost entirely financial: there was little concern about the academic or political implications of large numbers of overseas students' (1987, p. 16). The question of the learning experience is central within a more diverse community of students and some authors suggest that 'internationalisation has been driven largely by the marketisation discourse which has not been followed by the development of new pedagogical practices' (De Vita and Case, 2003, p. 384). Harris argued a decade ago that 'unless universities take seriously the implications of having overseas students, which include organizational and staff development issues as well as the proper adaptation of teaching methods and 
techniques, there is serious potential for things to go wrong' (1995, p. 77). Although efforts have recently been made to address this issue, there is still much to be done. While pedagogic innovations do not only rely on resources, fees should not be operating as substitution for public money if quality is to be maintained and diversity embraced. There are considerable risks in not meeting the pedagogic needs of international students. They may question the value for money of the offered programme and move to other countries. As Stiasny points out, 'international students have, simply, much more choice' (2008, p. $35)$.

Grants for home students and international scholarships for overseas students are instruments to promote social mobility at home and abroad. Such financial support is crucial in addressing 'the enormous challenge confronting higher education (which is) how to make international opportunities available to all equitably' (Altbach et al., 2009, p. 32). If overseas fees are mobilized as a substitution for slowing down public funding, there is an issue about the government's offer of international scholarships raising problems in terms of global social justice. It is worth noting that there was a temporary reduction of the number of overseas students following the two significant increases of fees in 1967 (for one year) and 1980 (for three consecutive years). The fact that numbers increased again afterwards may suggest that the impact of fees is not big on access. However, one can argue that a fee rise may change the social composition of the overseas students' body (figures are difficult to find) and increased global inequalities. According to a recent report, 'over 70 per cent of (overseas) students were paying fees and living costs from their own or their families' resources, except for research postgraduates, the majority of whom were funded by scholarships from other sources' (Council for International Education, 2004, p. 53).

It is difficult to find information about the number and value of scholarship for international students offered by government and other national scholarships (from the country of origin or the host country) as well as universities (which are developing rapidly in a context of institutional competition). The following therefore does not claim to offer a full picture. 
The Commonwealth Scholarship and Fellowship Plans are funded by the Department for International Development and the Foreign and Commonwealth Office. The Commonwealth Shared Scholarship Scheme is funded jointly by the Department for International Development and participating universities in the UK. The schemes support mainly postgraduate, although 50 per cent of overseas students are undergraduate. The number of awards nearly doubled over the last decade but this was mainly due to distance learning awards which share of total awards grew from a quarter to half from 2003 to 2007. From 1998 to 2007, the expenditure in real terms for commonwealth awards increased from 10 per cent. As a result the expenditure per awards nearly halved from 13, 362 to 7649 (this represents 0.5 per cent of all overseas students). Around 60 per cent and 30 per cent of these scholarships are offered to students from sub-Saharan Africa and 30 per cent from South Asia (Commonwealth Scholarships, 1997-2008).

Other scholarships are available like the British Chevening Scholarships funded by the Foreign and Commonwealth Office. Around 1000 postgraduate scholarships and 200 fellowships are offered each year. The Overseas Research Students Awards Scheme (ORSAS) is funded by the Department for Innovation, Universities and Skills for postgraduate non EU students. ORSAS funding pays the difference between the international and domestic student tuition fees and funds 600 students a year. HEFCE is to phase out funding from 2009-2010, when the grant will be reduced by a third, with a 50 per cent cut the next year and no funding from 2011 (http://www.orsas.ac.uk/england).

Thus only a few government scholarships are offered and most of them at postgraduate levels. No centralized data are available on scholarships from UK higher education institutions (which are increasingly important) and from students' country of origin. It is therefore difficult to know exactly how the student support system manages to promote international social justice and social mobility within the context of high fees. What is clear is that financial support has not matched the growth of fees and enrolment.

The main lesson from this discussion is that overseas fees (as well as home fees and arguably the other private resources of higher education) should be seen as additional resources and not substitutes. The continuation of the public/private substitution of 
funding may produce huge problems as more financial commitment demanded from overseas students would not be matched by sufficient public resources to increase funding per student (for both domestic and overseas students and not a transfer of resources between the two), to maintain a quality and diverse pedagogy with additional financial support for all students.

\section{Conclusion}

The political economy of higher education is constantly evolving and points to the dangers inherent in considering the present as permanent. The historical lens points to the combination of cultural, political, economic and financial motivations behind the expansion of numbers of overseas students. There have been tensions in the past between different, and sometimes contradictory, driving forces. However, the risk is that financial motivation tends to dominate the agenda to a point where the expansion of the higher education system in the direction of inclusion may suffer. This is especially important today as the recent financial crisis will probably alter the whole spectrum and debates about higher education.

Analysed in terms of the Kondratiev cycle, international students appear as forerunners of the greater financial contribution demanded of students after the 1970s economic crisis. This was part of the trend to substitute private funding for slowing down public resources rather than bringing additional income into higher education. This substitution failed to resolve the problems of underfunding and posed new equity issues. It is possible that the current economic crisis may test public-private substitution to the limit putting education institutions at the mercy of volatile private sources of funding.

The current crisis needs to be put in the context of increasing inequalities (Atkinson and Piketty, 2007). Private debts have in a sense masked the reality of inequalities brought by neoliberal controls on public spending. While higher education acts as a shield from unemployment, it may be the case that uncertainty and growing unemployment will deter more and more potential students from paying higher fees (even deferred). Some US banks have refused to offer student loans. Private resources from donations and 
businesses may also decrease. Recent events have shown us that private resources are more volatile and without substantial increase in public funding there is a risk of a return to a restricted expansion of higher education. Beyond the obvious impact on inequalities, such a move would mean that the global (neoliberal) agenda of public austerity has compromised the other agenda (and discourse) of the knowledge economy.

As globalization accelerated, Scott asks whether there is a conflict between massification of higher education and internationalization of universities (Scott, 1998, p. 121). To avoid this, it is crucial to consider both home and overseas students' fees as an additional income rather than substitute for public resources: the acceleration of public funding is crucial in order to generate an increase of funding per student (which was the stated goal of most reforms initially) to ensure fair access (through scholarships and grants) and improvement of quality for all students. The lens of economic cycles signals that previous economic downturns were overcome by countercyclical spending on human development and that higher education was part of that process. Only in the 1970s this did not occur, deepening the recession. The crisis offers the opportunity to return to a more balanced structure of funding for higher education and develop new mechanisms which could guarantee public funding independent from additional private funding. The provision of sufficient resources to develop a strong and inclusive higher education system contributing to social cohesion and national and global economy will require adequate public investment not private substitution.

\section{References}

Aldrich, R. (2002) A Century of Education (London: Routledge Falmer).

Altbach, P. G., Reisberg, L. and Rumbley, L. E. (2009) Trends in Global Higher Education: Tracking an Academic Revolution: A Report Prepared for the UNESCO 2009 World Conference on Higher Education (Paris: UNESCO).

Apple, M. (1982) Cultural and Economic Reproduction in Education (London: Routledge and Kegan Paul). 
Archer, L. and Leathwood, C. (2003) 'Identities, Inequalities and Higher Education', in Archer, L., Hutchings, M., and Ross, A. (eds) Higher Education and Social Class: Issues of exclusion and inclusion (London: Routledge Falmer).

Atkinson, A. B. and Piketty, T. (2007) Top Incomes over the Twentieth Century: A Contrast between European and English-Speaking Countries (Oxford: Oxford University Press).

Baker, I. (1993) 'Lessons from the Introduction of Fees for Overseas Students', Journal of Higher Education Policy and Management, 15(1), 95-98.

Ball, S. (2008) The Education Debate (Bristol: Polity Press).

Barr, N. (2003), 'Financing Higher Education: Lessons from the UK Debate', The Political Quarterly, 74(3), 371-381.

Belloc, B. (2003) 'Incentives and Accountability Instruments of Change', Higher Education Management and Policy, 1(1), 23-40.

Bjarnason, S. (2004) 'Borderless Higher Education', in King, R. (ed.) The University in the Global Age (Houndsmills: Palgrave Macmillan).

Boccara, P. (2008) Transformations et Crise du Capitalisme Mondialisé: Quelle Alternative? (Pantin: Le Temps des Cerises).

Bolsmann, C. and Miller, H. (2008) 'International Student Recruitment to Universities in England: Discourse, Rationales and Globalisation', Globalisation Societies and Education, 6(1), 75-88.

Bourdieu, P. and Passeron, J. C. (1964) Les héritiers, les étudiants et la culture (Paris: Editions de Minuit).

Bouslimani, A. (2002) 'La régulation systémique à l'épreuve de la problématique éducation-développement: vers l'élaboration de la notion de système social d'accumulation', Economies et Sociétés, Série F(40), 475-500.

Boyer, R. and Saillard, Y. (2002) Regulation Theory: The State of the Art (London: Routledge). 
Brown, R. (2004) 'The Future Structure of the Sector: What Price Diversity?', Perspectives, 8(4), 93-99.

Byram, M. and Dervin, F. (2008) Students, Staff and Academic Mobility in Higher Education (Newcastle: Cambridge Scholars Publishing).

Callender, C. and Jackson, J. (2005) 'Does the Fear of Debt Deter Students from Higher Education?', Journal of Social Policy, 34(4), 509-540.

Carpentier, V. (2001) Système éducatif et performances économiques au Royaume-Uni: 19 ème et 20ème siècles (Paris: L'Harmattan).

Carpentier, V. (2003) 'Public Expenditure on Education and Economic Growth in the UK, 1833-2000', History of Education, 32(1), 1-15.

Carpentier, V. (2004) Historical Statistics on the Funding and Development of the UK University System, 1920-2002, UK Data Archive. Online at www.dataarchive.ac.uk(accessed March 2010).

Carpentier, V. (2006a) 'Funding in Higher Education and Economic Growth in France and the United Kingdom, 1921-2003', Higher Education Management and Policy, 18(3), 1-26.

Carpentier, V. (2006b) 'Public Expenditure on Education and Economic Growth in the USA in the Nineteenth and Twentieth Centuries in Comparative Perspective', Paedagogica Historica, 42(6), 683-706.

Carpentier, V. (2007) 'Educational Policymaking: Economic and Historical Perspectives', in Crook, D. and McCulloch, G. (eds) History, Politics and Policy Making in Education (London: Bedford Ways Papers).

Carpentier, V. (2008) 'Quantitative Sources for the History of Education', History of Education, 37(5), 701-720.

Carpentier, V. (2009) 'Viewpoint: The Credit Crunch and Education: An Historical Perspective from the Kondratiev Cycle', London Review of Education, 7(2), 193196. 
Carry, A. (1999) 'Le compte satellite rétrospectif de l'éducation en France:1820-1996', Economies et Sociétés, Série AF(25), 1-281.

Castells, M. (2000) The Rise of the Network Society, 2nd ed. (New York: Blackwell Publishers).

Chattopadhyay, S. (2007) 'Exploring Alternative Sources of Financing Higher Education', Economic and Political Weekly, 20 October, 4251-4259.

Commonwealth Scholarships (1997-2008) Commonwealth Scholarship Commission in the United Kingdom, Annual Report to the Secretary of State for International Development.

Council for International Education (2004) Broadening Our Horizons: International Students in Uk Universities and Colleges (London: United Kingdom Council for Overseas Students' Affairs: The Council for International Education).

Dearing, R. (1997) The National Committee of Inquiry into Higher Education: Higher Education in the Learning Society (Norwich: Her Majesty's Stationary Office).

De Vita, G. and Case, P. (2003) 'Rethinking the Internationalisation Agenda in UK Higher Education', Journal of Further and Higher Education, 27(4), 383-398.

Diebolt, C. and Fontvieille, L. (2001) 'Dynamic Forces in Educational Development: A Long-Run Comparative View of France and Germany in the 19th and 20th Centuries', Compare, 31(3), 295-309.

Diouf, W. and Fontvielle, L. (2002) 'Développement de l'éducation, croissance économique et contrainte démographique dans les pays d'Afrique au Sud du Sahara', Economies et Sociétés, 40(3-4), 589-605.

Department for Education and Skills (DfES) (2003) The Future of Higher Education, White Paper, Department for Education and Skills, January.

Enslin, P. and Hedge, N. (2008) 'International Students, Export Earnings and the Demands of Global Justice', Ethics and Education, 3(2), 107-119. 
Fontvieille, L. (1976) 'Evolution et croissance de l'Etat français 1815-1969', Economies et Sociétés, Série AF(13), 1657-2149.

Fontvieille, L. (1990) 'Education, Growth and Long Cycles: The Case of France in the 19th and 20th Centuries', in Tortella, G. (ed.) Education and Economic Development since the Industrial Revolution (Valencia: Generalitat Valenciana).

Freeman, C. and Louçã, F. (2001) As Time Goes By, From the Industrial Revolutions to the Information Revolution (Oxford: Oxford University Press).

Galindo-Rueda, F., Marcenaro-Gutierrez, O. and Vignoles, A. (2004) 'The Widening Socio-Economic Gap in UK Higher Education', National Institute Economic Review, 190, 75-88.

Goodson, I. (2006) 'Long Waves of Educational Reform', in Goodson, I. (ed.) Learning, Curriculum and Life Politics: The Selected Works of Ivor F. Goodson (Abingdon: Routledge).

Gürüz, K. (2008) Higher Education and International Student Mobility in the Global Knowledge Economy (Albany, NY: State University of New York Press).

Harris, R. (1995) 'Overseas Students in the United Kingdom University System', Higher Education, 29(1), 77-92.

Harris, R. (1997) 'Overseas Students in the UK', in McNamara, D. and Harris, R. (eds) Overseas Students in Higher Education: Issues in Teaching and Learning (London: Routledge).

Held, D. and McGrew, A. (2002) The Global Transformation Reader, 2nd ed. (Cambridge: Polity).

Hobsbawm, E. J. (1997) On History (London: Abacus).

Jessop, B. (2002) The Future of the Capitalist State (Cambridge: Polity Press).

King, R. (2004) The University in the Global Age (Houndsmills: Palgrave Macmillan). 
Loucã, F. and Reijnders, J. (1999) The Foundations of Long Wave Theory (Cheltenham: Edward Elgar Publishing).

Lowe, R. (2008) The History of Higher Education (Series: Major Themes in Education, 5 Volumes) (London: Routlegde).

Maddison, A. (1995) Monitoring the World Economy 1820-1992 (Paris: Organisation for Economic Co-Operation and Development).

Maddison, A. (2000) The World Economy: A Millenial Perspective (Paris: Organisation for Economic Co-Operation and Development).

Marczewski, J. (1961) 'Histoire quantitative, buts et méthodes', Cahiers de l'Institut de Sciences Economiques Appliquées, Série A.F. 15, 3-54.

Marginson, S. and van der Wende, M. (2007) 'Globalisation and Higher Education', Organisation for Economic Co-Operation and Development (Education Working Paper No. 8).

Marx, K. (1894) Capital, Volume 1 (London: Laurence and Wishart, 1970).

McCulloch, G. (1998) 'Education and Economic Performance', History of Education, 27(3), 202-206.

Michel, S. (1999) Education et croissance économique en longue période (Paris: L'Harmattan).

Michel, S. and Vallade, D. (2007) 'Une Analyse de long terme des dépenses sociales', Revue de la régulation, 1, 1-32.

Milonakis, D. and Fine, B. (2009) From Political Economy to Economics: Method, the Social and the Historical in the Evolution of Economic Theory (London: Routledge).

Naidoo, R. (2003) 'Repositioning Higher Education as a Global Commodity: Opportunities and Challenges for Future Sociology of Education Work', British Journal of Sociology of Education, 24(2), 249-259. 
Olssen, M. and Peters, M. A. (2005) 'Neoliberalism, Higher Education and the Knowledge Economy: From the Free Market to Knowledge Capitalism', Journal of Education Policy, 20(3), 313-345.

Reay, D., David, M. and Ball, S. (2005) Degrees of Choice: Class, Race, Gender and Higher Education (Stoke-on-Trent: Trentham Books).

Sanderson, M. (2007) 'Educational and Economic History: The Good Neighbours', History of Education, 36(4-5), 429-445.

Scott, P. (ed.) (1998) The Globalization of Higher Education (Buckingham: Society for Research into Higher Education and Open University Press).

Serra, N. and Stiglitz, J. (2008) The Washington Consensus Reconsidered: Towards a New Global Governance (Oxford: Oxford University Press).

Silver, H. (2006) 'Things Change but Names Remain the Same: Higher Education Historiography 1975-2000', History of Education, 35(1), 121-140.

Sizer, J. (1987) 'The Impacts of Financial Reductions on British Universities: 1981-84', Higher Education, 16(5), 557-580.

Stiasny, M. (2008) Mobility Matters: 40 Years of International Students (London: United Kingdom Council for Overseas Students' Affairs: The Council for International Education).

Teixeira, J., Johnstone, B., Rosa, M. J. and Vossensteyn, H. (2006) Cost-sharing and Accessibility in Higher Education: A Fairer Deal? (Dordrecht: Springer).

Vickers, P. and Bekhradnia, B. (2007) The Economic Costs and Benefits of International Students (Oxford: Higher Education Policy Institute).

Wallerstein, I. (2003) 'Globalization or the Age of Transition? A Long-Term View of the Trajectory of the World-System', in Kohler, G. and Chaves, E. J. (eds) Globalization: Critical Perspectives (New York: Nova Science Publishers).

Watson, D. (2007) Managing Civic and Community Engagement (Buckingham: Open University Press). 
Watson, D. and Bowden, R. (2007) 'The Fate of the Dearing Recommendations: Policy and Performance in UK HE, 1997-2007', in Watson, D. and Amoah, M. (eds) The Dearing Report: Ten Years On (London: Bedford Way Papers).

Williams, G. (1987) 'The International Market for Overseas Students in the EnglishSpeaking World', European Journal of Education, 22(1), 15-25.

Williams, P. (1984) 'Britain's Full-Cost Policy for Overseas Students', Comparative Education Review, 28(2), 258-278.

Wolf, A. (2002) Does Education Matter? Myths About Education and Economic Growth (London: Penguin Books). 